\title{
Studies of cellular hypersensitivity to ionising radiation in Friedreich's ataxia
}

\author{
SUSAN CHAMBERLAIN, PAUL DLEWIS \\ From the Department of Histopathology, Royal Postgraduate Medical School, Hammersmith Hospital, London, UK.
}

SUMMARY Skin fibroblasts from seven patients with Friedreich's ataxia showed a small but significant increase in sensitivity to ionising radiation, as measured by post-irradiation clonal growth, when compared with cells from ten age-matched control subjects and from eight patients with motor neuron disease. Fibroblasts from three patients with Friedreich's ataxia also showed impairment of their ability to repair potentially lethal damage after ionising radiation. These findings are consistent with the view that defective DNA reparative mechanisms may be involved in the pathogenesis of Friedreich's ataxia.

The pathogenesis of many neurological system degenerative diseases, of which Friedreich's ataxia is an archetype, remains obscure. Amongst the casual factors that may be involved in this group of disorders defective DNA repair has been proposed. ${ }^{12}$ Several diseases affecting the nervous system, including xeroderma pigmentosum, ataxia telangiectasia and Cockayne's syndrome have been found to display - or are suspected of havingabnormalities of reparative DNA synthesis. ${ }^{3}$ The possibility that ineffectual DNA repair might compromise the function and viability of nerve cells has been raised, though this hypothesis still lacks direct experimental support.

Because of certain common clinical and pathological features shared by Friedreich's ataxia and the DNArepair-defective disorders xeroderma pigmentosum and ataxia telangiectasia, we initially examined skin fibroblasts from three patients with Friedreich's ataxia for evidence suggestive of DNA reparative abnormalities. ${ }^{4} 5$ In preliminary studies it was shown that Friedreich's ataxia cells were more sensitive to ionising radiation than control cells, as measured by the effect of graded doses of radiation on clonal growth. This finding is suggestive of defective DNA repair. It was further found that the pattern of newly-synthesised DNA in Friedreich's ataxia cells was abnormal. $^{6}$

The present report describes studies of cellular sensitivity to ionising radiation in an extended series of experiments on skin fibroblasts from seven patients with Friedreich's ataxia. Findings from parallel experiments on

Address for reprint requests: Dr Lewis, Royal Postgraduate Medical School, Hammersmith Hospital, London W12 OHS, UK.

Received 29 June 1982 and in revised form I September 1982 Accepted 3 September 1982 cells from eight patients with motor neuron disease and from ten control subjects are also reported.

In further experiments an examination has been made of the capacity of cells from three patients with Friedreich's ataxia and four control subjects to repair potentially lethal damage after exposure to ionising radiation. It is known that the survival of cells postirradiation can be influenced by environmental factors and is considerably enhanced if potentially lethal damage repair has time to occur in cells before they divide. ${ }^{7}$

Cells held in the $G_{1}$ phase of the generative cycle are able effectively to repair damage to DNA, thereby normalising the subsequent $S$ phase. ${ }^{8}$ Potentially lethal damage repair can be demonstrated by maintaining cultured cells in density- or growth-inhibiting conditions for a period after exposure to ionising radiation (or other DNA-damaging agent). Studies on potentially lethal damage repair in ataxia telangiectasia, which shows extreme hypersensitivity to $\mathrm{X}$-rays, indicate deficient repair in this disorder..$^{9} 10$

\section{Methods}

\section{Patients}

Forearm skin biopsies were obtained with informed consent from seven patients with clinically typical Friedreich's ataxia (three male, four female, age range 15-34 years) and eight patients with motor neuron disease (four familial and four sporadic; four male, four female, age range 44-73 years). All patients were examined neurologically and had biopsies taken by the senior author (PDL). Ten control fibroblast lines were obtained from healthy subjects (five male, five female, age range $12-40$ years) without evidence of any disease.

\section{Cell culture}

Cells were maintained in Eagle's medium supplemented by $10 \%$ new-born calf serum, penicillin $(25 \mathrm{iu} / \mathrm{ml})$, streptomycin $(25$ 
$\mu \mathrm{g} / \mathrm{ml})$ and glutamine $(2 \mathrm{mM})$. Cells were detached by means of $0.25 \%$ trypsin in Hank's basic salt solution (minus calcium and magnesium) and resuspended at appropriate density in medium with $15 \%$ fetal calf serum before X-irradiation at doses of $137 \cdot 5$, 275, 412 and 550 rads, using a $7 \mathrm{meV}$ linear accelerator. Clonal growth was then achieved in Eagle's medium supplemented with $15 \%$ calf serum, using the feeder layer technique, ${ }^{11}$ feeder cells having received a dose of 3000 rads. Fibroblasts from Friedreich's ataxia and motor neuron disease patients were irradiated and cloned in parallel with control cells. Cultures were sealed in polystyrene boxes, incubated for 17 days and stained with $2 \%$ Azur A. Colonies with more than 50 cells were counted as survivors. Cloning efficiency varied between $10 \%$ and $40 \%$. The fraction of cells surviving each dose of radiation was calculated taking into account the cloning efficiency of unirradiated cells, and for each cell line semilogarithmic survival curves were plotted. From these $D_{0}$ values (inverse of slope of linear part of curve) were obtained. For each cell line between one and seven replicate experiments were carried out.

\section{Measurement of potentially lethal damage repair}

Friedreich's aqtaxia and control cells were seeded at a density of $2.4 \times 10^{5}$ cells per flask in medium supplemented with $15 \%$ newborn calf serum. After 24 hours the medium was replaced with one containing $0.5 \%$ newborn calf serum and cells were then incubated at $37^{\circ} \mathrm{C}$ for five days to establish plateau-phase growth. After this time cells were irradiated with X-rays in the dose range up to 550 rads as before. "Zero time" cells were immediately plated out in medium supplemented with $15 \%$ newborn calf serum in numbers appropriate to dose and cloning efficiency, using the feeder layer technique as previously. Cells to be held in a growth-inhibited state had their medium changed to one containing $0.5 \%$ calf serum, and were incubated for a further 24 hours before being plated out in a $15 \%$ newborn calf serum-supplemented medium. All cells were then incubated for 17 days at $37^{\circ} \mathrm{C}$ in an environment containing $5 \%$ carbon dioxide, after which time clones formed from surviving fibroblasts were stained as before and counted for calculation of cell survival fractions and $D_{0}$ values.

\section{Results}

RADIOSENSITIVITYOFFRIEDREICH'S ATAXIA CELLS

Table 1 summarises the findings in 67 experiments in which the effect of X-irradiation on the clonal growth of fibroblasts from patients with Friedreich's ataxia and motor neuron disease and from control subjects was measured. Friedreich's ataxia cells appeared to be significantly more sensitive to radiation than control cells, showing an overall mean $\mathrm{D}_{0}$ value of 123.7 rads compared with 150.3 rads in controls. Only two of the seven Friedreich's ataxia cell lines had values falling within the normal range, and the difference between the two groups was significant at below the $1 \%$ level. In contrast motor neuron disease cells showed a mean $D_{0}$ value of $147 \cdot 1$ rads, which was not significantly different from that obtained for control cells.
Table 1 Effect of X-irradiation on clonal growth of fibroblasts from patients with Friedreich's ataxia $(F A)$, motor neuron disease (MND) and control subjects

\begin{tabular}{|c|c|c|c|}
\hline & \multicolumn{3}{|l|}{$D_{0}$ in rads } \\
\hline & Controls & $F A$ & $M N D$ \\
\hline & $\begin{array}{l}132(3) \\
152(3) \\
145(3) \\
168(3) \\
145(3) \\
185(2) \\
125(2) \\
128(2) \\
165(2) \\
158(2)\end{array}$ & $\begin{array}{l}122(3) \\
115(2) \\
104(3) \\
133(9) \\
122(2) \\
135(2) \\
120(1)\end{array}$ & $\begin{array}{l}150(3) \\
153(3) \\
155(3) \\
145(3) \\
150(3) \\
144(2) \\
144(2) \\
137(1)\end{array}$ \\
\hline $\begin{array}{l}\text { Overall mean } \\
\pm \text { SD }\end{array}$ & $150 \cdot 3 \pm 19 \cdot 2$ & $123 \cdot 7 \pm 20 \cdot 7^{*}$ & $147 \cdot 1 \pm 5 \cdot 9 \dagger$ \\
\hline
\end{tabular}

Experimental results are given for each case. Figures indicate mean $\mathrm{D}_{0}$ values (inverse of slope of linear part of survival curve). Number of replicate experiments for each case in parentheses.

$*$ Significant difference from controls; $\mathrm{p}<0.01$.

†Non-significant difference from controls.

Table 2 Effect of $X$-irradiation and subsequent 24 hour growth restriction on clonal growth of fibroblasts from Friedreich's ataxia patients (FA) and control subjects.

\begin{tabular}{|c|c|c|c|c|c|}
\hline \multicolumn{6}{|l|}{$D_{o}$ in rads } \\
\hline \multicolumn{3}{|l|}{ Controls } & \multicolumn{3}{|c|}{ Friedreich's ataxia } \\
\hline Zero time & \multicolumn{2}{|c|}{ 24-h held DMF } & \multicolumn{3}{|c|}{ Zero time 24-h held DMF } \\
\hline $\begin{array}{l}112(2) \\
114 \cdot 5(2) \\
93(2) \\
122(1)\end{array}$ & $\begin{array}{l}142 \\
142 \\
135 \\
148\end{array}$ & $\begin{array}{l}1 \cdot 27 \\
1 \cdot 24 \\
1 \cdot 45 \\
1 \cdot 21\end{array}$ & $\begin{array}{l}101 \cdot 5(3) \\
120(2) \\
103(2)\end{array}$ & $\begin{array}{l}115 \\
135 \\
126\end{array}$ & $\begin{array}{l}1 \cdot 13 \\
1 \cdot 13 \\
1 \cdot 22\end{array}$ \\
\hline \multicolumn{2}{|c|}{ Mean \pm SD } & \multicolumn{3}{|c|}{$1.28 \pm 0.06$} & $1 \cdot 15 \pm 0.05^{*}$ \\
\hline
\end{tabular}

Cells were maintained in growth-inhibiting conditions, irradiated with graded doses of X-rays up to 550 rads and either plated out immediately into normal growth medium (zero time) or kept in a growth-inhibited state for a further 24 hours (24-h held) to allow repair of potentially lethal damage. Cell colonies were counted after a further 17 days of normal growth. $\mathrm{DMF}=$ dose-modifying factor, or ratio of the mean $\mathrm{D}_{0}$ measurements obtained with these two treatments. Data from four control and three Friedreich's ataxia cell lines are shown, with number of replicate experiments in parentheses.

*Significant difference from controls: $p<0.02$.

POTENTIALLY LETHAL DAMAGEREPAIR IN FRIEDREICH'S ATAXIACELLS

Table 2 summarises findings in 14 experiments in which recovery after induction of potentially lethal damage by $\mathrm{X}$-irradiation in control and Friedreich's ataxia fibroblasts was measured. "Zero time" values for $\mathrm{D}_{0}$ obtained under growth-inhibited conditions are not comparable to those obtained previously for cells maintained continuously in logarithmic growth. However it is apparent that Friedreich's ataxia cells are able to recover from irradiation less well than control fibroblasts, and that the difference between the two groups in this measure of ability to repair radiation-induced damage is significant.

\section{Discussion}

The present findings indicate that cells from patients with Friedreich's ataxia show increased sensitivity to ionising 
radiation when compared with control cells. Although mild, the hypersensitivity found is statistically significant. In contrast, cells from patients with motor neuron disease showed the same range of $D_{0}$ values as did controls. It should be noted that while Friedreich's ataxia and control subjects were age-matched, motor neuron disease patients were all older. However any age effect in the present findings can be discounted because there appears to be no difference in $\mathrm{D}_{0}$ values with normal cells in the ranges three days to 46 years $^{12}$ and 23-35 years versus $64-75$ years. ${ }^{13}$

The biological significance of apparent cellular hypersensitivity to ionising radiation in Friedreich's ataxia remains to be proven, but the implication is that impaired capacity to repair DNA exists in this disease. This view is supported by the observation that Friedreich's ataxia cells appear to recover from X-ray-induced damage (presumed to be in DNA) less well than control fibroblasts. Further studies of potentially lethal damage repair in Friedreich's ataxia would seem necessary, as well as cell survival experiments using a range of mutagens with different effects on DNA ${ }^{14}$, before it could be firmly stated that Friedreich's ataxia is a DNA repair-deficient disorder.

The degree of radiosensitivity seen with Friedreich's ataxia cells is less than that found with other putative repair-deficient disorders and much less than that seen in ataxia telangiectasia, ${ }^{15} 16$ and potentially lethal damage repair, while apparently moderately impaired in Friedreich's ataxia, is known to be virtually absent in ataxia telangiectasia. ${ }^{10}$ Furthermore we have shown inhibition in post-irradiation DNA synthesis in Friedreich's ataxia cells but not in ataxia telangiectasia cells. ${ }^{6}$ For these reasons it would seem likely that the molecular abnormalities present in these two disorders are dissimilar.

By altering genetic information, deficient repair of damage induced in nuclear DNA by a wide range of mutagens could result in the death of long-lived, non-renewing and highly metabolically active cell populations, such as large neurons. ${ }^{2}$ Findings in fibroblasts in Friedreich's ataxia could thus provide a speculative explanation for the neurological changes seen in this disorder. Although it has previously been proposed that the loss of motor neurons in motor neuron disease might have a basis in defective DNA repair, ${ }^{17}$ the present findings do not support this speculation, though further studies using other mutagens would seem appropriate.

This work was supported by research grants from the Friedreich's Ataxia Group and the Medical Research Council.

\section{References}

' Andrews AD, Barrett SF, Robbins JH. Relation of DNA repair processes to pathological ageing of the nervous system in xeroderma pigmentosum. Lancet 1976;i:1318-20.

2 Andrews AD, Barrett SF, Robbins JH. Xeroderma pigmentosum neurological abnormalities correlate with colonyforming ability after ultraviolet radiation. Proc Natl Acad Sci USA 1978;75:1984-8.

${ }^{3}$ Arlett CF, Lehmann AR. Human disorders showing increased sensitivity to the induction of genetic damage. Ann Rev Genet 1978;12:95-115.

${ }^{4}$ Lewis PD, Corr JB, Arlett CF, Harcourt SA. Increased sensitivity to gamma irradiation of skin fibroblasts in Friedreich's ataxia. Lancet 1979;ii:474-5.

${ }^{5}$ Lewis PD, Corr JB. Increased radiosensitivity of skin fibroblasts in Friedreich's ataxia. Acta neuropathol (Berl) 1981;Suppl vii:230-2.

${ }^{6}$ Chamberlain S, Cramp WA, Lewis PD. Defects in newly synthesised DNA in skin fibroblasts from patients with Friedreich's ataxia. Lancet 1981;i:1165.

${ }^{7}$ Phillips RA, Tolmach LJ. Repair of potentially Jethal damage in X-irradiated HeLa cells. Radiation Res 1966;29:413-32.

${ }^{8}$ Little JB. Factors influencing the repair of potentially lethal radiation damage in growth-inhibited human cells. Radiation Res 1973;56:320-33.

${ }^{9}$ Weichselbaum RR, Nove J, Little JB. Deficient recovery from potentially lethal radiation damage in ataxia telangiectasia and xeroderma pigmentosum. Nature 1978;271:261-2.

${ }^{10}$ Cox R, Masson WK, Weichselbaum RR et al. Repair of potentially lethal damage in $\mathrm{X}$-irradiated cultures of normal and ataxia telangiectasia human fibroblasts. Int J Radiation Biol 1981;39:357-65.

"Cox R, Masson WK. Changes in radiosensitivity during the in vitro growth of diploid human fibroblasts. Int J Radiation Biol 1974;26:193-6.

${ }^{12}$ Weichselbaum RR, Nove J, Little JB. X-ray sensitivity of fifty-three human diploid fibroblast cell strains from patients with characterised genetic disorders. Cancer Res 1980;40:920-5.

13 Arlett CF, Harcourt SA. Survey of radiosensitivity in a variety of human cell strains. Cancer Res 1980;40:926-32.

14 Teo IA, Arlett CF, Harcourt SA, Priestley A, Broughton BC. Multiple hypersensitivity to mutagens in a cell strain (46 BR) derived from a patient with immuno-deficiencies. Mutation Res 1982; in press.

15 Taylor AMR, Harnden DG, Arlett CF, Harcourt SA, Lehmann AR, Stevens S, Bridges BA. Ataxia telangiectasia: a human mutation with abnormal radiation sensitivity. Nature 1975;258:427-9.

${ }^{16}$ Cox R, Hosking GP, Wilson J. Ataxia telangiectasia. Evaluation of radiosensitivity in cultured skin fibroblasts as a diagnostic test. Arch Dis Child 1978;53:386-90.

${ }^{17}$ Lewis PD. Abiotrophy revisited. In: Rose FC, ed. Motor Neurone Disease. Tunbridge Wells: Pitman, 1977:30-5. 